University of Nebraska - Lincoln

DigitalCommons@University of Nebraska - Lincoln

6-1-1991

\title{
Regulation of Biotechnology
}

Henry I. Miller

Food and Drug Administration

Robert H. Burris

University of Wisconsin, Madison, WI

Anne K. Vidaver

University of Nebraska-Lincoln, avidaver1@unl.edu

Follow this and additional works at: https://digitalcommons.unl.edu/plantpathpapers

Part of the Plant Pathology Commons

Miller, Henry I.; Burris, Robert H.; and Vidaver, Anne K., "Regulation of Biotechnology" (1991). Papers in Plant Pathology. 85.

https://digitalcommons.unl.edu/plantpathpapers/85

This Article is brought to you for free and open access by the Plant Pathology Department at DigitalCommons@University of Nebraska - Lincoln. It has been accepted for inclusion in Papers in Plant Pathology by an authorized administrator of DigitalCommons@University of Nebraska - Lincoln. 
HENRY I. MILLER, ROBERT H. BURRIS, and ANNE K. VIDAVER

Regulation of Biotechnology

Published in

Science, Jun 1991; 252: 1599 - 1600. 
Regulation of Biotechnology

Greg Simon (Letters, 3 May, p. 629) makes the case that only federal regulation of releases of agricultural products will address health and safety concerns. Such a view is hardly surprising, since he drafted the federal statute for the comprehensive regulation of field research with recombinant DNA-manipulated organisms. The basic assumptions of this statute were contrary to those contained in the reports of the National Academy of Sciences (NAS) (1) and the National Research Council (NRC) (2) and also to the existing policies of government research and regulatory agencies. The statute would have regulated only those organisms that were manipulated with recombinant DNA techniques (and virtually all of them), but not organisms likely to be of high risk, such as those possessing enhanced fitness or pathogenicity or those that contain novel phenotypes. Such a statute would not have allayed public fears or conferred safety protection above that of current regulation, but it would have perpetuated the notion that process, rather than performance or product, should be the focus of regulation. It would, inevitably, have exerted a chilling effect on those wishing to use the newest techniques. This scientifically indefensible approach was criticized by government agencies, industry, and academia alike and was rejected by Congress.

Simon criticizes the congruence of the principles underlying our proposal (Policy Forum, 26 Oct., p. 490) with those elaborated in reports from the NAS and the NRC. He criticizes us for not relying instead on a position paper by the Ecological Society of America (ESA) (3). We believe the NAS-NRC principles are scientifically defensible and internally consistent but that the statements of the ESA, which are dependent on process, are not. The ESA paper agreed with the NAS and NRC that there is no fundamental difference between new and old techniques of genetic manipulation with respect to risk for organisms used in field trials, but it concluded that every proposed field trial of an organism manipulated with recombinant DNA techniques-without any expression or exemption-must be sub- 
jected to a governmental risk assessment.

However, agricultural research even with plants or microbes that have been powerfully modified by a variety of traditional genetic techniques, has not been routinely subject to governmental "case by case every case" evaluation, except for certain plant pests, noxious weeds, or organisms considered to be veterinary vaccines. And when one considers that an individual plant breeder "may introduce into the field 50,000 genotypes per year on average or $2,000,000$ in a career" $(2$, p. 66), and that many of these are transgenic, it is clear that the logic of the ESA's position is flawed (4).

Simon cites what he considers to be another contradiction between the NAS-NRC reports and the ESA paper, noting the NASNRC conclusion that intergeneric organisms present no unique hazards per se and that most engineered organisms are expected to be less fit than their parental organisms. He continues, "Conversely, [the ESA report] predicts that '[o]rganisms with novel combinations of traits are more likely to play novel ecological roles.' " These statements are not necessarily incompatible. An intergeneric organism may not represent a "novel combination of traits" with respect to ecological, genetic, or even phenotypic factors. Conversely, intrageneric genetic changes can confer changes that exert drastic effects. As we emphasized one must consider carefully the function of coding or regulatory elements that have been transferred; less important is the technique used to confer the genetic change or the presumed evolutionary distance between the nucleic acids being recombined.

Simon characterizes our proposal as "too little" and derides it as "self-regulation." Actually, it provides an algorithm that has unlimited flexibility. Depending on what is judged to be an acceptable regulatory burden on researchers and the government, an appropriate level of scrutiny for certain organisms, and other factors, the mechanism can vary widely-from an extremely stringent scheme with a high proportion of required case-by-case governmental risk assessments to a more laissez-faire one in which there is complete exemption or a requirement only for notification for the majority of experiments. Whatever the choice, the cardinal principles of sound regulation would be met.

HeNRY I. MILLER Office of Biotechnology, Food and Drug Administration, Rockville, MD 20857

ROBERT H. BURRIS Department of Biochemistry,
University of Wisconsin, Madison, WI 53706

ANNE K. VIDAVER

Department of Plant Pathology,

University of Nebraska, Lincoln, NE 68583

REFERENCES AND NOTES

1. National Academy of Sciences, "Introduction of recombinant DNA-engineered organisms into the environment: Key issues" (National Academy Press, Washington, DC, 1987).

2. National Research Council, "Field testing genetically modified organisms: Framework for decisions" (National Academy Press, Washington, DC, 1989).

3. Ecological Society of America, Ecology 70, 298 (1989).

4. The recent U.S. Kiawah Island International Symposium (November 1990), "Biosafety Results of Field Tests of Genetically Modified Plants and Microorganisms," at which the results of nearly 150 field trials were described, affirmed at least the short-term predictability of the safety of recombinant DNA-manipulated organisms. 